\title{
Present Day Mutations Prove Theoretical Possibility of Prehistoric/Historical Emergence of East Asian Phenotype from Caucasians via Inbreeding
}

\author{
Mister Seun Ayoade* \\ Physiology, University of Ibadan, Oyo State, Nigeria
}

Submission: March 09, 2018; Published: March 15, 2018

*Corresponding author: Mister Seun Ayoade, BSc (Hons) Physiology, University of Ibadan, Oyo State, Nigeria, Email: seunoodua@yahoo.com

\section{Short Communication}

Table 1

\begin{tabular}{|c|c|}
\hline Condition & Associated mutation \\
\hline Down's syndrome & $\begin{array}{c}\text { presence of all or part of a third copy of } \\
\text { chromosome 21 }\end{array}$ \\
\hline $\begin{array}{c}\text { Foetal alcohol } \\
\text { syndrome }\end{array}$ & $\begin{array}{c}\text { Chromosomal microduplications or } \\
\text { microdeletions [1] }\end{array}$ \\
\hline Turner syndrome & $\begin{array}{c}\text { Female partly or completely missing an X } \\
\text { chromosome }\end{array}$ \\
\hline Phenylketonuria & $\begin{array}{c}\text { Mutations in the PAH gene which results in low } \\
\text { levels of the enzymephenylalanine hydroxylase. } \\
\text { This results in the build-up of dietary } \\
\text { phenylalanine to potentially toxic levels }\end{array}$ \\
\hline Williams syndrome & $\begin{array}{c}\text { a deletion of about 27 genes from the long arm } \\
\text { of one of the two chromosome 7s }\end{array}$ \\
\hline Noonan syndrome & autosomal dominant congenital disorder \\
\hline $\begin{array}{c}\text { Rubinstein-Taybi } \\
\text { syndrome }\end{array}$ & Defects in the genes CREBBP and EP300 \\
\hline $\begin{array}{c}\text { Blepharophimosis } \\
\text { syndrome }\end{array}$ & mutations in the FOXL2 gene \\
\hline
\end{tabular}

One of the characteristic physical features of East Asians is the presence of an epicanthus i.e. epicanthic fold. Under some medical conditions however, Europeans do exhibit this trait. Medical conditions causing anomalous epicanthic folds and mutations associated with such conditions include in Table 1. The above are all harmful mutations producing epicanthic folds as just one of the associated features. Epicanthic folds by themselves are not harmful, so it is not completely unreasonable to suggest that sometime in the past harmless mutations could have produced epicanthic folds. And these harmless/neutral mutations could've been triggered by inbreeding among early men.

\section{Hypothesis}

creationists insist all human beings descended from just two people. If this is true those first two humans were probably extreme Caucasians [1,2], with descendants getting darker due to increasing melanin levels via inbreeding. Inbreeding can likewise account for the emergence of "slant eyed" Asians from Caucasian ancestors via harmless mutations $[3,4]$.

\section{References}

1. Edward A Mead, Dipak K Sarkar (2014) Fetal alcohol spectrum disorders and their transmission through genetic and epigenetic mechanisms. Front Genet 5: 154.

2. Mister SA (2018) If the Bible is Literally True, Adam and Eve were Most Likely Platinum Blonde Caucasians. J0J Nurse Health Care 6(3): 1-2.

3. Bittles AH (2010) Consanguinity, Genetic Drift, and Genetic Diseases in Populations with Reduced Numbers of Founders. In: Speicher MR, Motulsky AG, Antonarakis SE (Eds.), Vogel and Motulsky's human genetics problems and approaches ( $4^{\text {th }}$ edn.), Springer-Verlag, Berlin, Germany, pp. 507-528.

4. The Habsburg Lip (2013) Topics in the History of Genetics and Molecular Biology, Fall 2000. 
This work is licensed under Creative Commons Attribution 4.0 License

DOI: 10.19080/JOJNHC.2018.06.555696

\section{Your next submission with Juniper Publishers} will reach you the below assets

- Quality Editorial service

- Swift Peer Review

- Reprints availability

- E-prints Service

- Manuscript Podcast for convenient understanding

- Global attainment for your research

- Manuscript accessibility in different formats

( Pdf, E-pub, Full Text, Audio)

- Unceasing customer service

Track the below URL for one-step submission https://juniperpublishers.com/online-submission.php 